\title{
The Community Needs to Research Problem Development in Areas Under the Responsibility of Suan Sunandha Rajabhat University
}

\author{
Rosjana Chandhasa ${ }^{1}$, Suwaree Yordchim ${ }^{2}$ \& Phusit Phukamchanoad ${ }^{3}$ \\ 1 Faculty of Fine and Applied Arts, Department of Creative Products Design, Suan Sunandha Rajabhat \\ University, Thailand \\ ${ }^{2}$ Faculty of Humanities and Social Sciences, Department of Business English Program, Suan Sunandha Rajabhat \\ University, Thailand \\ ${ }^{3}$ Faculty of Humanities and Social Sciences, Department of Social Development Management, Suan Sunandha \\ Rajabhat University, Thailand
}

Correspondence: Rosjana Chandhasa, Faculty of Fine and Applied Arts, Department of Creative Products Design, Suan Sunandha Rajabhat University, Thailand. Tel: 66-955-181-285. E-mail: rosjana.ch@ssru.ac.th

Received: August 11, $2018 \quad$ Accepted: November 6, $2018 \quad$ Online Published: November 29, 2018

doi:10.5539/ass.v14n12p1 URL: https://doi.org/10.5539/ass.v14n12p1

\begin{abstract}
This study aimed to investigate the community needs in the areas under the responsibility of Suan Sunandha Rajabhat University in order to propose the research problem. Regarding research procedures, the qualitative research method was initially employed to collect data, and the data was consequently analyzed to create the research problem to examine the communities. The scopes of this study were separated into three parts comprising: firstly, the scope of areas under the responsibility of Suan Sunandha Rajabhat University consisted of 1) Dusit - Phranakhon in Bangkok, 2) Khlong Yong in Nakhon Pathom, 3) Sarapee, Bangkontee in Samut Songkhram, 4) Ban Muang - Ban Wang Thong, Kham Chanod in Udon Thani and 5) Ngao, Muang Ranong in Ranong. Secondly, the scope of contents was used to investigate community needs in the area under the responsibility of Suan Sunandha Rajabhat University. Lastly, the scope of samples employed the simple random sampling by drawing lots technique in specifying the samples. The samples were classified into 3 major groups including 100 farmers, 100 SME entrepreneurs, 100 OTOP entrepreneurs as well as 30 government officials. according to the research instruments, the interview form and questionnaire which their questions based on the conceptual framework were used in the in-depth interview as well as participant observation to gather information about community needs. Furthermore, the focus group discussion was also applied into collecting data in the five areas under the responsibility of Suan Sunandha Rajabhat University.

The results elucidated that the problems which the researcher could further utilize in creating the research problem involved with economy, environment, education as well as health. In each area, there was a variety of needs on different context. For instance, the community needs to research problem development in the areas of Sarapee village, Bangkontee district in Samut Songkhram, Khlong Yong district in Nakhon Pathom and Ngao sub-district, Muang Ranong district in Ranong related to agricultural-product processing due to the fact that these areas mainly produced a large number of agricultural products. In addition, the needs toward health in all areas were consistent (e.g., promoting the community to have better knowledge about disease prevention as well as health care).
\end{abstract}

Keywords: community needs, responsibility, research problem development, Suan Sunandha Rajabhat University

\section{Introduction}

The economic development of the country has to emphasize the community which is considered as the crucial part that can propel the economic activity from a foundation. It normally depends upon the citizen's problems and needs to strengthen community as well as simultaneously create its income. There has been an operation which can be concretely measured by using accurate criteria. Additionally, there is an explicit community income which is a result of the cooperation among government, private as well as civil society sectors. It can increase the community income which consequently makes Thai economy reach the stability, prosperity and sustainability according to the Thailand's vision towards economy development initiated at the foundation level 
which is specified by Thai government. As seen, the agriculture continues to play an important role in the economy due to the fact that it entails not only income, but also agricultural career opportunities (e.g., farmers, fishermen, or big-animal livestock, such as beef cattle and small-animal livestock, such as chickens, pigs). Nevertheless, the many agriculturists still have a problem on insufficient income to live, and some of them produce agricultural products which does not meet market demand or have the standard guarantee. In addition, some agriculturists concern only their own farm without making agreement which causes the competitive limitation as well as agricultural disparity. Besides the agriculture section, around three million people including entrepreneurs of Small and Medium Enterprises (SMEs) and One-Tambon One-Product (OTOP) project or 98 percent of the whole entrepreneurs are considered as the important mechanism in driving the economy of the country. However, they still have weaknesses involving administration and management in various ways, especially; there is only a small number of connection between government sector and entrepreneurs as well as among entrepreneurs. Most SMEs and OTOP entrepreneurs normally run their business alone without network support; therefore, if this situation remains unchanged, there will be the business drawbacks or limitation. As Thai entrepreneurs have to prepare themselves to deal with the Asian Economic Community or AEC policy in the near future, the business management standard and the regional as well as national business partnership establishment have to be enhanced in order to be ready for AEC. Furthermore, the SMEs and OTOP entrepreneurs also have to adjust themselves to the changes as well as improve their business in various ways to push the limit of competitiveness nowadays. Ministry of Industry is the agency that plays a key role in promoting and developing entrepreneurship as well as providing projects under the Strategic Development Plan of industry ministry which delivers services involving competitiveness development to overtake the change of the modern world.

Regarding moving forward to community development which responds the policy of the provincial economy on different aspects, and accomplishes the indicated university vision, policy and strategy in developing community, the researcher has a critical consideration on the necessity in conducting a survey as well as a study on the community problems and needs to be a data base in creating the research problems. This causes conducting research by having community participation for the systematic exploration and development. The result of this study can also be precisely delivered to community academic services; therefore, in order to efficiently bring about the community development responding to the strategy-based policy of the province and university as well as community needs, the investigation on community needs to develop research problems in areas under the responsibility of Suan Sunandha Rajabhat University is needed. Suan Sunandha Rajabhat University is the university that links, and has a good relationship with the community by achieving the community needs and delivering the academic services to the community in informing the knowledge to community which can coincidently make reputation to the university. The conducting research and delivering academic services have to be specifically based on studying community about the area, need and research participation to generate the solutions for the requirements, and the knowledge from conducting the research can be a source of information which can illustrate a good relationship between community and university.

This can be an echo of being a university for local and community development which is consistent with the provincial strategy-based policy in diverse ways. Hence, in order to meet the vision, policy and local development strategy of the university, the research and development institute has to conduct a survey and study on community needs in the areas under the responsibility involving academic services of the university to analyze the existing community's problems and needs as a data base for further use on research as well as academic services in order to get the accurate response on community needs which is in accordance with strategic-based policy of the province and university regarding the community development. The study of needs towards potential development of the community under the Public-Private Collaboration policy which counts on the Sufficiency Economy philosophy is used as a primary source in investigating needs of farmers, SME/OTOP entrepreneurs and travel business in order to be precisely developed and applied, and consequently to provide the research problems as well as academic services. If this research is not conducted, it will affect the future research on task complexity as well as inaccurate response to community needs. For this reason, it will entail no usefulness on invested budget. On the other hand, if the research provides the information presented in this study, it will be advantageous to planning strategies to develop research and academic services. Besides, government-agency network in the areas can also realize the good points about participating of farmers, SME/OTOP entrepreneurs and travel business whom are guided by the university as a supervisor in conducting research to the product development for strengthening and sustaining community's economy foundation.

\section{Research Objectives}

To investigate the community needs in the areas under the responsibility of Suan Sunandha Rajabhat University 
in order to propose the research topic.

\section{Research Methodology}

In this study, a qualitative research method was initially employed to gather data, and the received data was consequently analyzed to create the research problem in order to examine the communities.

\subsection{Scope of Research}

The scope of this study was classified as follows:

1) The scope of areas under the responsibility of Suan Sunandha Rajabhat University including (1 Dusit Phranakhon in Bangkok, (2 Khlong Yong in Nakhon Pathom, (3 Sarapee, Bangkontee in Samut Songkhram, (4 Ban Muang - Ban Wang Thong, Kham Chanod in Udon Thani and (5 Ngao, Muang Ranong in Ranong.

2) The scope of contents in investigating community needs in the area under the responsibility of Suan Sunandha Rajabhat University.

3) The scope of samples utilizing the simple random sampling method by using drawing lots in specifying the representatives of each sample. The samples were classified into 3 major groups including 100 farmers, 100 SME entrepreneurs, 100 OTOP entrepreneurs as well as 30 government officials. All samples were collected data about the needs in order to be analyzed and synthesized to propose the research problem in developing the communities for the university teachers in conducting the further development.

\subsection{Research Instrument}

The research instruments used in this study including:

1) The in-depth interview and participant observation were conducted to gather information about community needs by using the interview form and questionnaire based on the conceptual framework.

2) The focus group discussion was applied into collecting data in the five areas under the responsibility of Suan Sunandha Rajabhat University.

\section{Data Collection and Data Analysis}

Research Procedure 1: Preparation and data collection

(1) Hold a meeting to inform activities, prepare readiness as well as make a mutual understanding

(2) Review information from relevant documents and related studies in order to create a research problem

(3) Analyze and synthesize the data of each area under the responsibility of Suan Sunandha Rajabhat University (overall including 5 areas)

Research Procedure: 2 Gathering data of each area under the responsibility of Suan Sunandha Rajabhat University (overall including 5 areas).

Table 1. The result of the community needs in Sarapee village, Bangkontee district, Samut Songkhram

\begin{tabular}{ll}
\hline \multicolumn{1}{c}{ Four Types of the Community Needs in Samut Songkhram Area } \\
\hline 1. Economy & $\begin{array}{l}\text { - Agricultural-product processing (e.g., pommel, coconut, lychee) } \\
\text { - Establishment of professional group in recycling agricultural leftovers }\end{array}$ \\
\hline 2. Environment & $\begin{array}{l}\text { - Environmental management inside the community, such as providing incinerators as a result of a } \\
\text { large number of community waste which was seriously difficult to manage, holding a project in } \\
\text { understanding as well as conducting research for further solutions }\end{array}$ \\
\hline 3. Education & $\begin{array}{l}\text { - Short courses of vocational training } \\
\text { - Education for youth and community leaders }\end{array}$ \\
\hline 4. Health & - Wellness and health of elderly people \\
\hline
\end{tabular}

According to Table 1, the community needs in Samut Songkhram area could be divided into 4 types including economy, environment, education and health. The overview of community needs involved with a requirement to have research conduct in order to solve the overproduction of agricultural products as well as promote the knowledge of villagers in the community about developing management systems, processing products, using products by considering worthiness as well as strengthening and sustaining the community.

It was demonstrated in Table 2 that the community needs in Dusit - Phranakhon districts in Bangkok area were categorized into 4 types which were: economy, environment, education and health. The overview was that there was a need on community commercial space (e.g., community markets), waste management, IT education, 
knowledge of health as well as disease prevention.



Figure 2. The Samut Songkhram Community

Table 2. The result of the community needs in Dusit - Phranakhon districts in Bangkok

\begin{tabular}{ll}
\hline & \multicolumn{1}{c}{ Four Types of the Community Needs in Bangkok Area } \\
\hline 1. Economy & - Providing community commercial spaces, such as community markets were required. \\
\hline 2. Environment & - Improving waste management in the community \\
\hline 3. Education & - Community library construction and community IT education \\
\hline \multirow{3}{*}{ 4. Health } & - Health development of children, youth, general publics and elderly people \\
& - Using knowledge related to food consumption to avoid diseases \\
& - Campaigning to help the young generations keep away from drug \\
\hline
\end{tabular}

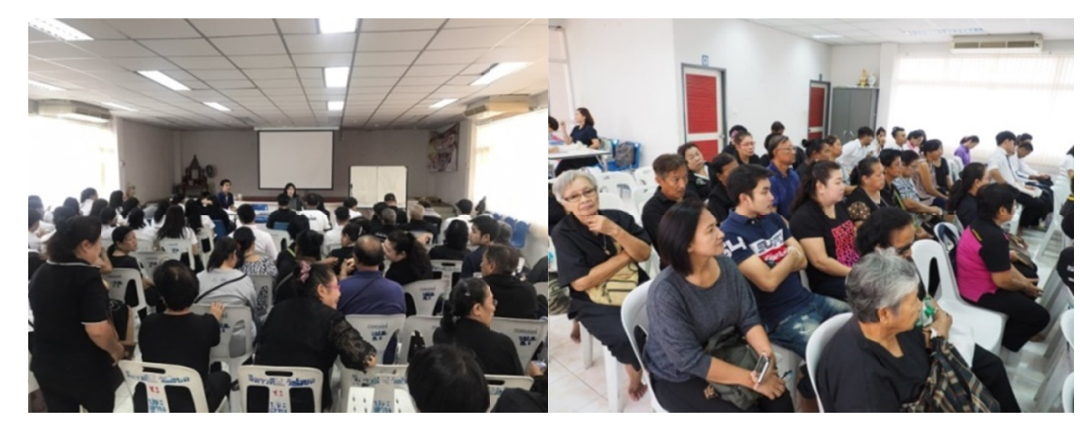

Figure 3. The Dusit - Phranakhon Community in Bangkok

Table 3. The result of the community needs in Khlong Yong district in Nakhon Pathom

Four Types of the Community Needs in Nakhon Pathom Area

- Brand design, international product name, unique product packaging development as well as technology for preserving products, food and fruits were needed.

- Promoting the water tourism as there are staffs who presently responsible for informing about

1. Economy traveling at Khlong Mahasawat floating market.

- Promoting the province to be the safe food supplier as well as to be a producer of agricultural products, agro-Industrial products and industrial products for export.

- Promoting ecotourism as well as enhancing life quality and sustainable development.

- Environment and forestry conservation was needed.

2. Environment - Research on water hyacinth (e.g., mushroom cultivation using water hyacinth or charcoal briquettes from water hyacinth) was required.

3. Education

- Having sufficient number of teachers

- Providing English Teaching for youth

4. Health

- Promoting health care to people in the community

- Promoting self and family health care

Table 3 showed that the community needs in Nakhon Pathom area were divided into 4 types consisting of economy, environment, education and health. An overview of the community illustrated that the community mainly required the development of product processing, product preservation and uniqueness as well as universality of OTOP goods. Moreover, promoting the water tourism (e.g., Khlong Mahasawat floating market) and ecotourism as well as removing water hyacinth and transforming into products and charcoal briquettes were also required. Regarding the education, the number of teachers as well as English teaching should be sufficiently 
provided to the community. Besides, the disease prevention and treatment using natural therapy were demanded on the needs about health.

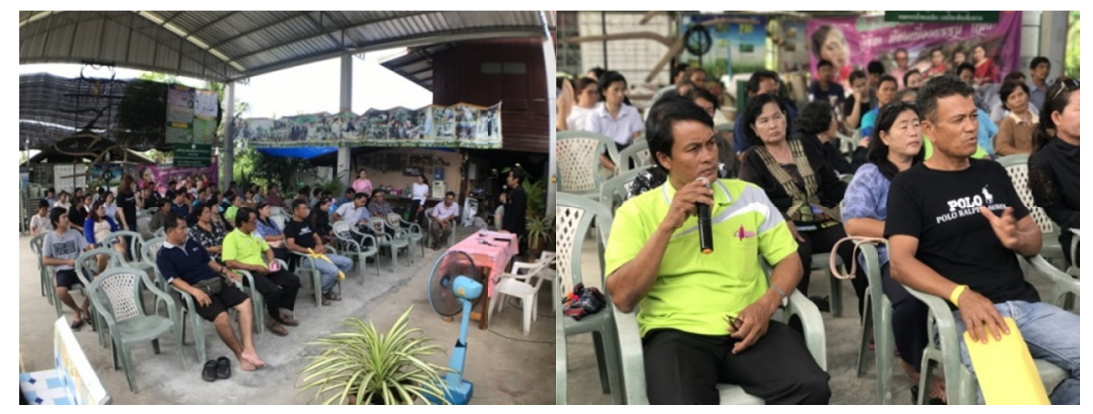

Figure 4. The Nakhon Pathom Community

Table 4. The result of the community needs in Ngao sub-district, Muang Ranong district in Ranong

\begin{tabular}{ll}
\hline & \multicolumn{1}{c}{ Four Types of the Community Needs in Ranong Area } \\
\hline \multirow{3}{*}{ 1. Economy } & - Developing professionals and OTOP goods \\
& - Developing packaging of OTOP products to reach a wider market \\
& - Developing products from cashew nuts \\
& - Providing comprehensive travel including services, hotel or resort, souvenirs and public relations \\
\hline & - Conservation of aquatic animals for sustainable fishery by harvesting at a suitable rate as well as \\
& conserving at the same time and providing water resources to respond to the consumption demand and \\
2. Environment & $\begin{array}{l}\text { developing community water supply systems to be sufficient to alleviate drought conditions during dry } \\
\text { - Stimulating awareness and consciousness of people in the community to participate in natural resources } \\
\text { and environmental conservation as well as promoting aquatic animals conservation by extending } \\
\text { aquaculture areas or harvesting aquatic animals with the correct and legal ways (e.g., selecting proper } \\
\text { fishing tools) }\end{array}$ \\
\hline 3. Education & $\begin{array}{l}\text { - Improving knowledge and understanding of children, youth and people in the community to be aware of } \\
\text { cultural and social problems in order to achieve the sustainable community development }\end{array}$ \\
\hline 4. Health & $\begin{array}{l}\text { - Providing efficient health care to all people in the community } \\
\text { - Creating community participation in disease prevention surveillance }\end{array}$ \\
\hline
\end{tabular}

Conforming to Table 4, the community needs in Ranong area could be separated into 4 types comprising of economy, environment, education as well as health. The overview of the community need was described as: In economy, the community required developing professionals and OTOP goods, developing packaging of OTOP products for a wider market, developing cashew-nut products and providing comprehensive travel including services, hotel or resort, souvenirs and public relations. In environment, the community needed conserving aquatic animals for sustainable fishery by harvesting at a suitable rate as well as conserving at the same time, providing water resources to respond to the consumption demand and developing community water supply systems to be sufficient to alleviate drought conditions during dry seasons and stimulating community awareness and consciousness to participate in natural resources and environmental conservation as well as promoting aquatic animals conservation by expanding aquaculture areas or harvesting aquatic animals with the correct and legal ways (e.g., selecting proper fishing tools). Additionally, in education, the community demanded improving knowledge and understanding of children, youth and people in the community in order to be aware of cultural and social problems to achieve the sustainable community development. Besides, in health, the community needed providing efficient health care to all people in the community as well as creating community participation in disease prevention surveillance.

It was elucidated in the Table 5 that the community needs in Ban Muang - Ban Wang Thong, Kham Chanod in Udon Thani area were classified into 4 types which were: economy, environment, education and health. The overview of community needs on economy involved with promoting tourism, improving food and product transformation and preservation, solving the problems related to product price fall owing to the overproduction. For the weaving community, packaging design/conducting workshops on creating packaging, developing new patterns of weaving textile, transforming loincloth into a bag, trousers, shirt and other products were needed. Furthermore, the community also required Transforming reed mats into a bag, conducting workshops on designing new patterns of weaving mat and dying without discoloration as well as teaching transforming cattail 
in order to increase its value. Regarding the needs on environment, the water shortages in the dry seasons should be solved. In addition, the need on education was teaching English for moving forward to ASEAN, and the need on health related to community health care and health care training, teaching making a grass broom as well as designing basic exercise machines for using in a house, and campaigning people in the community to stop alcohol drinking/smoking.

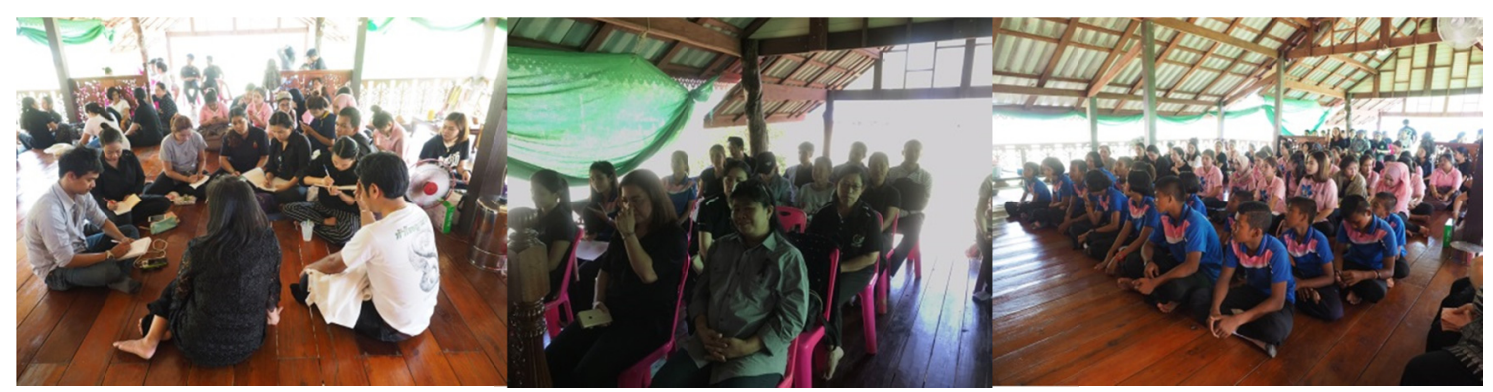

Figure 5. The Ranong Community

Table 5. The result of the community needs in Ban Muang - Ban Wang Thong, Kham Chanod in Udon Thani

\begin{tabular}{cl}
\hline & \multicolumn{1}{c}{ Four Types of the Community Needs in Udon Thani Area } \\
\hline & - Promoting tourism \\
& - Food preservation as well as solving the problems related to product price fall due to the overproduction. \\
& - The weaving community needed packaging design/conducting workshops on creating packaging, \\
developing new patterns of weaving textile, transforming loincloth into a bag, trousers, shirt and other \\
products.
\end{tabular}



Figure 6. The Udon Thani Community

\section{Conclusion of Research Result}

Conforming to the findings of the community needs in the areas under the responsibility of Suan Sunandha Rajabhat University to research problem development, the results of the 5 areas were illustrated in the form of table as follows:

Table 6. The example of applying the community needs into developing research problems in the area of Sarapee village, Bangkontee district, Samut Songkhram

\begin{tabular}{lll}
\hline Type & Lists of Need & Example of Research Problem \\
\hline \multirow{3}{*}{$\begin{array}{l}\text { 1. Economy } \\
\text { 1. Agricultural-product processing (e.g., }\end{array}$} & $\begin{array}{l}\text { 1. The study on lychee peel extract to create beauty products, } \\
\text { such as lychee toner, cleansing gel or skincare. }\end{array}$ \\
& $\begin{array}{l}\text { 2. Establishment of professional group in } \\
\text { recycling agricultural leftovers }\end{array}$ & $\begin{array}{l}\text { 2. The study of properties of pommel peel in producing plant } \\
\text { nutrition products, such as vegetable growth stimulant. }\end{array}$ \\
\hline \multirow{2}{*}{ 2. Environment } & $\begin{array}{l}\text { Environmental management inside the } \\
\text { community, such as providing incinerators }\end{array}$ & $\begin{array}{l}\text { The management system learning and eco-friendly waste } \\
\text { incinerator design to set zero on waste }\end{array}$ \\
\hline
\end{tabular}


as a result of a large number of community waste which was seriously difficult to manage, holding a project in informing knowledge on waste management for villagers due to their insufficient waste-management understanding as well as conducting research for further solutions

$\begin{array}{ll}\text { 3. Education } & \text { 2. Short courses of vocational training } \\ & \text { Education for youth and community }\end{array}$ leaders

4. Health Wellness and health of elderly people
1. The curriculum study and design to develop creativity and career for Samut Songkhram community

2. The development of teaching and learning to develop educational personnel and children to step to become a 21 st century school of the academic institutions in Samut Songkhram educational service area

1. The study on nutritional value in selecting food consisting with the age and context of the community

2. The study of farmers' behavior and toxin in their body to protection and healthcare to help them keep away from chemicals

3. The study on food and nutrition for elderly people

4. Developing elderly's care systems for elder people who live by themselves

According to Table 6, the demonstration of research problem examples in developing community from investigating community needs in the Samut Songkhram area under the responsibility of Suan Sunandha Rajabhat University involved informing the knowledge from conducting the research to the community to help people perceive approaches, models and lessons, and further study in developing their agricultural products as well as encouraging community members to overcome the community problems. In education, for example, the community had to conduct the research on the curriculum study and design to develop creativity and career for Samut Songkhram community as well as the development of teaching and learning to develop educational personnel and children to step to become a 21 st century school of the academic institutions in Samut Songkhram educational service area.

Table 7. The example of applying the community needs into developing research problems in the area of Dusit Phranakhon districts in Bangkok

\begin{tabular}{lll}
\hline Type & Lists of Need & Example of Research Problem \\
\hline 1. Economy & $\begin{array}{l}\text { The community needed commercial spaces, } \\
\text { such as community markets }\end{array}$ & $\begin{array}{l}\text { The design and establishment of community trade center in } \\
\text { Dusit - Phra Nakhon in Bangkok }\end{array}$ \\
\hline 2. Environment & Waste management in the community & $\begin{array}{l}\text { The management system learning and eco-friendly waste } \\
\text { incinerator design to set zero on waste }\end{array}$ \\
\hline & & $\begin{array}{l}\text { 1. The curriculum study and design to develop creativity and } \\
\text { career for Dusit - Phra Nakhon, Bangkok community }\end{array}$ \\
3. Education & $\begin{array}{l}\text { 1. The community library construction } \\
\text { 2. The community IT education }\end{array}$ & $\begin{array}{l}\text { 2. The development of teaching and learning to develop } \\
\text { educational personnel and children to step to become a 21st } \\
\text { century school of the academic institutions in Dusit - Phra } \\
\text { Nakhon, Bangkok educational service area }\end{array}$ \\
\hline $\begin{array}{l}\text { 1. Health development of children, youth, } \\
\text { general publics and elderly people } \\
\text { 2. Using knowledge related to food } \\
\text { consumption to avoid diseases and young } \\
\text { generations keep away from drug }\end{array}$ & $\begin{array}{l}\text { 1. The study on nutritional value in selecting food consisting } \\
\text { with the age and context of the community }\end{array}$ \\
& $\begin{array}{l}\text { 2. The study on food and nutrition for elderly people } \\
\text { 3. Developing youth's care systems to keep away from drug }\end{array}$ \\
\hline
\end{tabular}

It was presented in Table 7 that research problem examples in developing community which linked with investigating community needs in the Dusit - Phranakhon, Bangkok area under the responsibility of Suan Sunandha Rajabhat University were different due to the dissimilarity of social context as well as community distinction. The community in downtown needed shops or community markets in order to distribute own goods. Regarding the environment, waste was still a main community problem. Moreover, the accessible IT information (e.g., knowledge on how to use computers or using smartphones for communication) was required for education in the community. Besides, in health, there were deficiencies on ground for sports as well as activities for young generations to reduce addiction problem. 
Table 8. The example of applying the community needs into developing research problems in the area of Khlong Yong district in Nakhon Pathom

\begin{tabular}{|c|c|c|}
\hline Type & Lists of Need & Example of Research Problem \\
\hline 1. Economy & $\begin{array}{l}\text { 1. Developing brand design, international product } \\
\text { name, unique product packaging development as } \\
\text { well as technology for preserving products, food } \\
\text { and fruits } \\
\text { 2. Promoting the province to be the safe food } \\
\text { supplier as well as agricultural product, } \\
\text { agricultural-and-industrial product and industrial } \\
\text { product producer for export as well as promoting } \\
\text { ecotourism and enhancing life quality and } \\
\text { sustainable development } \\
\text { 3. Promoting the water tourism as there are staffs } \\
\text { who presently responsible for informing about } \\
\text { traveling at Khlong Mahasawat floating market }\end{array}$ & $\begin{array}{l}\text { 1. The study of identity and culture to create brand and } \\
\text { agricultural product packaging of Nakhon Pathom } \\
\text { communities } \\
\text { 2. Promoting and developing vegetable growing systems } \\
\text { as well as organic agricultural products for Nakhon } \\
\text { Pathom agricultural tourism promotion } \\
\text { 3. Developing the water tourism "Khlong Mahasawat" } \\
\text { model in order to improve community-based tourism in } \\
\text { Nakhon Pathom }\end{array}$ \\
\hline 2. Environment & $\begin{array}{l}\text { Conducting research on water hyacinth (e.g., } \\
\text { mushroom cultivation using water hyacinth or } \\
\text { charcoal briquettes from water hyacinth) }\end{array}$ & $\begin{array}{l}\text { Innovating water hyacinth fiber for developing appliances } \\
\text { as well as home decorations in Nakhon Pathom }\end{array}$ \\
\hline 3. Education & $\begin{array}{l}\text { 1. The community library construction } \\
\text { 2. English teaching for young generations }\end{array}$ & $\begin{array}{l}\text { 1. The design and establishment of community libraries } \\
\text { in Nakhon Pathom based on community participation } \\
\text { 2. The development of English language curriculum for } \\
\text { young generations to the establishment of English for } \\
\text { communication clubs }\end{array}$ \\
\hline 4. Health & $\begin{array}{l}\text { 1. Promoting health care to people in the } \\
\text { community } \\
\text { 2. Promoting self and family health care }\end{array}$ & $\begin{array}{l}\text { Providing food and health caring systems for Nakhon } \\
\text { Pathom communities }\end{array}$ \\
\hline
\end{tabular}

Table 8 regarding research problem examples in developing community from investigating community needs in the Nakhon Pathom area under the responsibility of Suan Sunandha Rajabhat University revealed that the area was abundant as well as had a large number of non-toxic agricultural products. However, those products remained undeveloped, and lacked of promoting value. There was also the lack of promoting community participation in sustaining own area improvement. According to the economy, the researcher generated the research problem examples as: The study of identity and culture to create brand and agricultural product packaging of Nakhon Pathom communities, promoting and developing vegetable growing systems as well as organic agricultural products for Nakhon Pathom agricultural tourism promotion as well as developing the water tourism "Khlong Mahasawat" model in order to improve community-based tourism in Nakhon Pathom. For the environment, there was water hyacinth fiber innovation for developing appliances as well as home decorations in Nakhon Pathom. In addition, for the education, the design and establishment of community libraries in Nakhon Pathom based on community participation and the development of English language curriculum for young generations to the establishment of English for communication clubs were enriched. Furthermore, there was food and health caring systems provision for Nakhon Pathom communities in health section.

Table 9. The example of applying the community needs into developing research problems in the area of Ngao sub-district, Muang Ranong district in Ranong

\begin{tabular}{|c|c|c|}
\hline Type & Lists of Need & Example of Research Problem \\
\hline 1. Economy & $\begin{array}{l}\text { 1. Developing career and OTOP goods } \\
\text { 2. Developing OTOP packaging to reach a } \\
\text { wider market } \\
\text { 3. Developing products from cashew nuts } \\
\text { 4. Providing comprehensive travel including } \\
\text { services, hotel or resort, souvenirs and public } \\
\text { relations }\end{array}$ & $\begin{array}{l}\text { 1. The study and development of OTOP products and } \\
\text { creating careers to increase the capacity of Ranong } \\
\text { community } \\
\text { 2. Design and development of OTOP product packaging to } \\
\text { enhance community product standards for export } \\
\text { 3. Developing travel routes, accommodations and services for } \\
\text { tourism to raising and enhancing Ranong's industrial } \\
\text { competitiveness }\end{array}$ \\
\hline 2. Environment & $\begin{array}{l}\text { 1. Conservation of aquatic animals for } \\
\text { sustainable fishery by harvesting at a suitable } \\
\text { rate as well as conserving at the same time } \\
\text { and providing water resources to respond to } \\
\text { the consumption demand and developing }\end{array}$ & $\begin{array}{l}\text { 1. Community participation in conserving natural resources } \\
\text { to sustainably preserve natural balance in Ranong } \\
\text { 2. Community participation in enlightening community } \\
\text { awareness and consciousness toward aquatic-animal } \\
\text { conservation and propagation for the sustainability of Ranong }\end{array}$ \\
\hline
\end{tabular}


community water supply systems to be sufficient to alleviate drought conditions during dry season

2. Stimulating awareness and consciousness of people in the community to participate in natural resources and environmental conservation as well as promoting aquatic animal's conservation by extending aquaculture areas or harvesting aquatic animals with the correct and legal ways (e.g., selecting proper fishing tools)

3. Education Improving knowledge and understanding of children, youth and people in the community to be aware of cultural and social problems in order to achieve the sustainable community development

$\begin{array}{ll}\text { 4. Health } & \begin{array}{l}\text { Providing efficient health care to all people in } \\ \text { the community and creating community } \\ \text { participation in disease prevention } \\ \text { surveillance }\end{array}\end{array}$

It was elucidated on Table 9 that research problem examples in developing community and investigating community needs in the Ranong area under the responsibility of Suan Sunandha Rajabhat University had the properties as: the area was mountainous, and had beautiful scenery. Moreover, there was hot spring which was considered as the most popular tourist attraction of Ranong. The climate in Ranong was simply described as eight-month raining and four-month summer. The province well-known product was cashew nut. The overview on economy of Ranong was that the community demanded knowledge on research in order to develop products and services. For instance, in the economy section, the community needed studying and developing OTOP products and creating careers to increase the capacity of Ranong community, designing and improving OTOP product packaging to enhance community product standards for export as well as developing travel routes, accommodations and services for tourism to raising and enhancing Ranong's industrial competitiveness.

Table 10. The example of applying the community needs into developing research problems in Ban Muang and Ban Wang Thong, Kham Chanod in Udon Thani

\begin{tabular}{ll}
\hline Type & Lists of Need \\
\hline 1. Economy & 1. Promoting tourism \\
& 2. Food preservation and processing as well as \\
& solving the problems of agricultural product \\
& overproduction which entailed product price fall \\
& 3. The weaving community needed packaging \\
& design/conducting workshops on creating \\
packaging, developing new patterns of weaving & \\
& textile, transforming loincloth into a bag, \\
trousers, shirt and other products. & 4. Transforming reed mats into a bag, conducting \\
& workshops on designing new patterns of weaving \\
& mat and dying without discoloration. As there \\
& were myriad of cattail in the community without \\
& utilizing, the transforming cattail in order to \\
increase its value should be taught.
\end{tabular}

2. Environment Solutions for water shortages in the dry season

3. Education Teaching English for moving forward to ASEAN

4. Health Providing health care and health care training to the community, teaching making a grass broom as well as designing basic exercise machines which could be used in a house, and campaigning people in the community to stop alcohol drinking/smoking
Example of Research Problem

1. Strategic development and tourism promotion

2. Agricultural product processing innovation

3. Product design and development by using Udon Thani local weaving fabric

4. The study of cultural identity to Udon Thani local weaving fabric pattern design

5. Appliance and home decoration design and development using Udon Thani reed mats

The study of community participation in water management as well as promoting economical use of water in Udon Thani

The English for communication curriculum study and design for Udon Thani community to upgrade as well as extend its capacity limit

1. The study of community context to design a body care program consisting with each age range in order to sustainably reduce community health problems

2. The study of herb to reduce alcohol drinking and smoking in Udon Thani. 
From, the research problem examples in developing community and investigating community needs in the Udon Thani area under the responsibility of Suan Sunandha Rajabhat University demonstrated that the area had an ancient civilization as well as it was dominated by wisdom in various fields, such as weaving textile, basketry and mat. Additionally, the community also had a variety of important cultural tourist attractions which could reflect the economic growth of Udon Thani. For instance, strategic development and tourism promotion, agricultural product processing innovation, product design and development by using Udon Thani local weaving fabric, the study of cultural identity to Udon Thani local weaving fabric pattern design or appliance and home decoration design and development using Udon Thani reed mats.

\section{Discussion of Research Result}

The results of this study revealed that the five areas under the responsibility of Suan Sunandha Rajabhat University were a learning center involving research conduction as well as academic services which were managed and instructed by the community leader since the authority which was responsible for operating annual research conduction of the university to investigate the needs of all learning centers in the fiscal year 2018 in order to generate the research problems as information for researchers or scholars in Suan Sunandha Rajabhat University to realize the ideas in conducting research to respond to the community needs, and the research from this kind of conduction normally had a practical contribution. The findings of each area in this study could be summarized as follows:

1. The research problem examples in developing community from investigating community needs in the Samut Songkhram area under the responsibility of Suan Sunandha Rajabhat University involved with informing the knowledge from conducting the research to the community to help people perceive approaches, models and lessons, and further study in developing their agricultural products as well as encouraging community members to overcome the community problems. In education, for example, the community had to conduct the research on the curriculum study and design to develop creativity and career for Samut Songkhram community as well as the development of teaching and learning to develop educational personnel and children to step to become a 21 st century school of the academic institutions in Samut Songkhram educational service area.

2. The research problem examples in developing community which linked with investigating community needs in the Dusit - Phranakhon, Bangkok area under the responsibility of Suan Sunandha Rajabhat University were different due to the dissimilarity of social context as well as community distinction. The community in downtown needed shops or community markets in order to distribute own goods. Regarding the environment, waste was still a main community problem. Moreover, the accessible IT information (e.g., knowledge on how to use computers or using smartphones for communication) was required for education in the community. Besides, in health, there were deficiencies on ground for sports as well as activities for young generations to reduce addiction problem.

3. The research problem examples in developing community from investigating community needs in the Nakhon Pathom area under the responsibility of Suan Sunandha Rajabhat University revealed that the area was abundant as well as had a large number of non-toxic agricultural products. However, those products remained undeveloped, and lacked of promoting value. There was also the lack of promoting community participation in sustainable own area improvement. According to the economy, the researcher generated the research problem examples as: The study of identity and culture to create brand and agricultural product packaging of Nakhon Pathom communities, promoting and developing vegetable growing systems as well as organic agricultural products for Nakhon Pathom agricultural tourism promotion as well as developing the water tourism "Khlong Mahasawat" model in order to improve community-based tourism in Nakhon Pathom. For the environment, there was water hyacinth fiber innovation for developing appliances as well as home decorations in Nakhon Pathom. In addition, for the education, the design and establishment of community libraries in Nakhon Pathom based on community participation and the development of English language curriculum for young generations to the establishment of English for communication clubs were enriched. Furthermore, there was food and health caring systems provision for Nakhon Pathom communities in health section.

4. The research problem examples in developing community and investigating community needs in the Ranong area under the responsibility of Suan Sunandha Rajabhat University had the properties as: the area was mountainous, and had beautiful scenery. Moreover, there was hot spring which was considered as the most popular tourist attraction of Ranong. The climate in Ranong was simply described as eight-month raining and four-month summer. The province well-known product was cashew nut. The overview on 
economy of Ranong was that the community demanded knowledge on research in order to develop products and services. For instance, in the economy section, the community needed studying and developing OTOP products and creating careers to increase the capacity of Ranong community, designing and improving OTOP product packaging to enhance community product standards for export as well as developing travel routes, accommodations and services for tourism to raising and enhancing Ranong's industrial competitiveness.

5. The research problem examples in developing community and investigating community needs in the Udon Thani area under the responsibility of Suan Sunandha Rajabhat University demonstrated that the area had an ancient civilization as well as it was dominated by wisdom in various fields, such as weaving textile, basketry and mat. Additionally, the community also had a variety of important cultural tourist attractions which could reflect the economic growth of Udon Thani. For instance, strategic development and tourism promotion, agricultural product processing innovation, product design and development by using Udon Thani local weaving fabric, the study of cultural identity to Udon Thani local weaving fabric pattern design or appliance and home decoration design and development using Udon Thani reed mats.

The mentioned findings were consistent with the result of studying community participation in community plans toward the infrastructure development in Talad Kwan sub-district, Doi Saket district in Chiang Mai proposed by Nongnuch Kruasri (2009) which aimed to investigate the community plans toward the infrastructure development as well as the role of citizen in conducting community plans that the citizen had demands on providing community plans in developing the infrastructure which relied on the community management system. Its purposes were to initiate a project related to the infrastructure in order to (1) meet the citizen's requirements, (2) determine the suitable duties and responsibilities for relevant people, and (3) co-create the visions, goals as well as approaches in improving the infrastructure. It was also suggested in the study that there should be citizen participation to exchange experiences in developing community as well as there should be applying the local wisdom in enhancing approaches and overcoming problems for the sustainable solution. In accordance with Proyrungroj, R. (2015). It said poor people in the community can truly enjoy the benefit from tourism.

\section{References}

Chareonwongsak, K. (2006). Strategic Thinking. Bangkok: Success Media Co., Ltd.

Kruasri, N. (2009). Public Participation in Community Plan Process on Infrastructure Development of Talat Khwan, Doi Saket, Chiang Mai. Independent Study of Master of Arts, Faculty of Political Science and Administration, Graduate School, Chiang Mai University.

Maslow, A. (1970). Motivation and Personality. New York: Harper and Row Publishers.

Priyakorn, P. (2001). Strategic Planning - Applied Concepts and Approaches. Bangkok: Sema Dhamma Press.

Rattana, K. (2006). Participation in Watershed Management. Bangkok: Kasetsart University, Faculty of Forestry, Department of Conservation.

Suppharanon, S. (2006). Competitive Strategies to Create Advantages for Perpetual Overcome. Bangkok: V Print Printing House Co., Ltd.

\section{Copyrights}

Copyright for this article is retained by the author(s), with first publication rights granted to the journal.

This is an open-access article distributed under the terms and conditions of the Creative Commons Attribution license (http://creativecommons.org/licenses/by/4.0/). 